turers and the rest of society, the governing classes in particular. He agrees that this state of affairs will not be quickly cured. But, shamefully, he is not sure whether the report will ever be published, saying that it would identify for competitors the weak points in British industry, as if they did not know already.

Economic statistics point to one disturbing structural weakness in the British economy: at times of economic growth, the balance of external payments for goods traded internationally tends to go awry. In other words, British industry cannot satisfy the demands of its domestic market when people have money in their pockets. If and when the present recession ends, that effect promises an old-fashioned balance-of-payments crisis whose severity will be the first objective measure of the degree to which the decline of British industrial capacity has been further exacerbated by the recession. The continuing announcements from large companies of their intentions to make workers redundant hint at what is happening. Corporate bankruptcies have been running at more than 60,000 a year for some years.

It is more disturbing that very similar diagnoses of Britain's economic weakness have been produced regularly for the best part of the past half-century. Immediately after the Second World War, several working groups of the AngloAmerican Productivity Council pointed to the scant attention paid to innovation and the employment of innovators in British industry. In 1957, the British Association for the Advancement of Science (whose serious influence has itself since declined) produced an influential document saying much the same. With a few exceptions (pharmaceuticals now), British industry seems to have lost both the flair and the appetite for major technical innovations.

So much is clearly witnessed by the decision of the London Stock Exchange last week that it will abandon a software project for the automatic settlement of stock sales and purchases on which it has already spent $£ 75$ million, perhaps a third of total spending on the project. Although the Thatcher governments seemed often to believe that the decline of manufacturing would be immaterial if there were a compensating growth in the provision of services, there can hardly be a more vivid proof that, these days, even the sale of services requires technical competence of a high order.

The bearing of all this on the planned white paper on research is obvious. Crude attempts to force applicable innovations out of the research community may harm research but, in themselves, do nothing for prosperity. What good is a technical innovation that, when patented or otherwise protected, is not fully exploited? That is why an effective policy for research directed at wealth-creation must hang on more successful attempts than there have been so far to make manufacturing companies more technically skilled and competent - more aware of their dependence on skilled people for their success. But that, of course, lies outside the remit of the minister responsible, Mr William Waldegrave. But Heseltine's leaked document should at least give him ammunition with which to fend off simplistic demands from Heseltine's department.

\section{Angry summer time}

Britain is out of step with the rest of Europe even on matters such as summer time. But that may change.

WITH summer approaching, the issue of British daylight saving has once again appeared above the horizon, seemingly bent on pursuing its annual ascent through the political firmament. At a conference last month, the vociferous Daylight Extra Action Group renewed its call for Britain to get into step with the rest of Europe by setting its clocks to Central European Time (CET), an hour ahead of Greenwich Mean Time (GMT), Britain's winter standard which is adjusted every summer by one hour (as in the rest of Europe). But despite the usual grumblings, the well-worn arguments about whether it is more dangerous for a child to walk home from school in the dark than it is for a farmer to operate a combine harvester without proper visibility, the opposition to synchronization seems to have all but caved in.

The British government has traditionally tried to minimize its involvement with this surprisingly emotive debate. In 1989, it issued a consultation document outlining the options as it saw them. Britain could make a wholesale transition to CET, the so-called 'single-double summertime' option, involving a two-hour leap forward one spring, and a step back of an hour the same autumn; it could go half-way, and synchronize the end-date of Britain's summer with the rest of Europe (at present there is about a month's discrepancy); or it could leave things exactly as they are.

Feedback from the public was conflicting. The more that rural northern Britain was in favour of preserving the status quo, the more the south called for CET. The whole issue, in short, became politically rather sensitive. Relief came, in the end, from an unexpected quarter. A review by minister Peter Lloyd after the Conservatives' surprise general-election victory last year revealed a movement gaining momentum among Eurocrats in Brussels to abolish summer time altogether. The French particularly, whose agricultural lobby makes daily headlines by its restlessness in the free global marketplace, appear to be in favour of this Scroogeish sounding proposal, providing the British government, until the issue is settled, with the perfect excuse for keeping the issue on a back-burner.

But domestic pressure may yet force the government's hand. According to Angus Creighton-Miller of the Daylight Extra Action Group, the National Farmers' Union has assured him that its members are "pretty agnostic" these days about daylight saving, and are unlikely to lobby against any move that results in an extra hour of darkness every morning. Those in favour of the switch, by contrast, have never been more outspoken. Last month's conference called for a quick switch to Central European Time "so that lives can be saved and the quality of life be enhanced for all". The government may well listen if it wins the Maastricht Bill it is fighting through the House of Commons, but otherwise may not have the stomach for even this modest European venture. 